\title{
AKTIVITAS ENZIM PEROKSIDASE PISANG KEPOK DENGAN APLIKASI GLOMUS TIPE 1
}

\author{
Suswati $^{1}$, Asmah Indrawaty ${ }^{1}, \&$ Friardi $^{2}$ \\ ${ }^{1}$ Program Studi Agroteknologi, Fakultas Pertanian, Universitas Medan Area \\ Jl. Kolam No 1 Medan Estate, 20223 \\ ${ }^{2}$ Fakultas Farmasi, Universitas Andalas \\ Kampus Unand Limau Manis, 25163 \\ E-mail: suswatifebri@gmail.com
}

\begin{abstract}
Ripe banana peroxidase activities with Glomus type 1. Ripe banana is very susceptible to blood disease caused by Blood disease bacterium (BDB) and Fusarium wilt caused by Fusarium oxysporum f.sp. cubense. Arbuscular mycorrhizal fungi (AMF) Glomus tipe 1 increased resistance of ripe banana seedlings to both wilt diseases. The resistance mechanism related with the change of hydrolytic enzyme activities: peroxidase (PO), phenylalanin amonialyase (PAL) and polyphenoloksidase (PPO). The green house and laboratorium experiment were conducted to study the effect of different colonization time 4, 12, $24,36,48,72,96 \mathrm{~h}$ after application (haa) and control (without AMF) with 3 replicates. AMF fresh inoculants source is a mixture of sand planting medium that containing spores, hyphae and corn root colonized AMF. Ripe banana seedlings (60 days old) were inoculated with $50 \mathrm{~g}$ fresh AMF inoculants and incubated with the treatment. The results showed that the application of Glomus tipe 1 caused changes in the enzyme activity of peroxidase in the roots and leaves. Root peroxidase enzyme activity slightly increased $5.84 \%(0.326 \mathrm{U})$ at the beginning of colonization (4 haa) while peroxidase enzyme activity in leaves sharply declined (85.83-87.37\%).
\end{abstract}

Key words: arbuscular mycorrhizal fungi, blood disease bacterium, Fusarium oxysporum f.sp. cubense, Glomus tipe 1, peroxidase enzyme activities, ripe banana

\begin{abstract}
ABSTRAK
Aktivitas enzim peroksidase pisang kepok dengan aplikasi Glomus tipe 1. Tanaman pisang kepok sangat rentan terhadap penyakit layu bakteri yang disebabkan oleh Blood Disease Bacterium (BDB) dan layu Fusarium oleh Fusarium oxysporum f.sp. cubense (Foc). Aplikasi Glomus tipe 1 mampu meningkatkan ketahanan tanaman pisang kepok terhadap kedua penyakit tersebut. Peningkatan ketahanan tanaman pisang tersebut berkaitan erat dengan perubahan aktivitas enzim hidrolitik seperti peroksidase (PO), phenylalanin amonialyase (PAL) dan polypeniloksidase (PPO). Tujuan penelitian adalah mengukur aktivitas enzim peroksidase dan kadar protein tanaman pisang kepok setelah aplikasi Glomus tipe 1. Sebanyak $50 \mathrm{~g}$ inokulan Glomus tipe 1 diaplikasi pada perakaran bibit pisang kepok umur 2 bulan setelah aklimatisasi. Kolonisasi mikoriza pada perakaran bibit pisang Kepok disesuaikan dengan perlakuan waktu kolonisasi yaitu 4, 12, 24, 36, 48, 72, 96 jam setelah aplikasi (jsa) dan kontrol (tanpa mikoriza). Parameter yang diamati adalah aktivitas enzim peroksidase dan kadar protein tanaman pisang kepok dengan metode Lowry. Hasil penelitian menunjukkan bahwa aplikasi Glomus tipe 1 menyebabkan perubahan aktivitas enzim peroksidase dalam akar dan daun. Aktivitas enzim peroksidase akar sedikit meningkat 5,84\% (0,326U) pada awal kolonisasi (4 jsa) sementara aktivitas enzim peroksidase dalam daun mengalami penurunan yang tajam $(85,83-87,37 \%)$.
\end{abstract}

Kata kunci: aktivitas enzim peroksidase, blood disease bacterium, fungi mikoriza arbuskular, Glomus tipe 1, Fusarium oxysporum f.sp.cubense, pisang kepok

\section{PENDAHULUAN}

Blood Disease Bacterium (BDB) merupakan patogen utama yang menginfeksi tanaman pisang di Indonesia dan menyebabkan penurunan hasil 20-100\% (Sulyo, 1992). Bakteri ini mampu menyerang semua stadia pertumbuhan tanaman pisang (bibit, tanaman dewasa ataupun tanaman yang telah membentuk tandan) (Wardlaw, 1972) dan bersifat mematikan dengan menginfeksi jaringan pembuluh tanaman secara sistemik (Eden-Green, 1992).

Pengendalian penyakit darah sulit dilakukan karena propagul infektif BDB dapat bertahan hingga 1-2 tahun dalam tanah dan jaringan tanaman terserang 
tanpa kehilangan virulensinya. Tingginya propagul infektif BDB di dalam tanah mengakibatkan tidak produktifnya lahan-lahan endemik pertanaman pisang. Berbagai upaya pengendalian bakteri tersebut seperti penggunaan bibit tanaman sehat, tidak menanam tanaman inang lainnya (Heliconia sp.), sanitasi kebun dan pembuatan saluran drainase, menjarangkan anakan, pengapuran, menghindari terjadinya pelukaan akar saat pemeliharaan tanaman, pengerodongan bunga dan buah dengan plastik, memotong bunga jantan (jantung pisang), eradikasi tanaman terserang dengan cara membongkar tanaman dan membakarnya atau dengan menyuntikkan minyak tanah pada batang semu tanaman terserang (10-20 ml per tanaman) tidak memberikan hasil yang maksimal. Sampai saat ini belum ada metode pengendalian patogen ini yang berhasil secara ekonomis (Buddenhagen \& Elsasser, 1962; Ploetz, 1990), sehingga sangat diperlukan aplikasi agensia hayati untuk menekan propagul BDB seperti aplikasi Fungi mikoriza arbuskular (FMA) indigenus. Berbagai hasil penelitian membuktikan bahwa FMA memiliki efek bioprotective terhadap patogen-patogen soilborne (Singh et al., 2000; AzconAguilar et al., 2002; Xavier \& Boyetchko, 2004; StArnaud \& Elsen, 2005; St-Arnaud \& Vujanovic, 2007).

FMA indigenus yang berasal dari rizosfer tanaman inang sejenis akan lebih mudah beradaptasi dengan tanaman uji sejenis dan kompatibilitasnya tinggi pula. Aplikasi Glomus tipe 1 dan Acaulospora tipe 4 yang diisolasi dari rizosfer tanaman pisang kepok di lahan endemik BDB Kecamatan Baso, Kabupaten Agam, Sumatera Barat dapat menginduksi tanaman pisang kepok terhadap BDB dalam pengujian rumah kaca (Suswati et al., 2007). Hasil pengujian ketahanan bibit pisang kepok di rumah kaca diperoleh hasil bahwa mikoriza Glomus tipe 1 dapat meningkatkan ketahanan bibit pisang kepok terhadap BDB, bibit pisang yang diaplikasi mikoriza tersebut tidak terserang BDB hingga umur 120 hari setelah inokulasi (hsi) sementara bibit pisang dengan aplikasi Acaulospora tipe 4 menampakkan gejala serangan berupa kelayuan tanaman pada 7 hsi dan tanaman tanpa aplikasi FMA (kontrol) terinfeksi lebih cepat (6 hsi). Glomus tipe 1 dapat menekan perkembangan BDB hingga 100\%, sementara isolat Acaulospora tipe 4 hanya mampu menekan perkembangan BDB sebesar 16,67-50\%. Pada pengujian rumah kaca aplikasi FMA yang berasal dari rizosfer tanaman pisang kepok dapat menurunkan persentase dan intensitas serangan BDB hingga 100\% dan pada pengujian lapangan dapat menurunkan intensitas serangan BDB hingga 90,8\%. Penekanan perkembangan patogen tersebut ditemukan pada perakaran bibit pisang yang sehat dengan persentase kolonisasi 81-90\% dan kelas intensitas 4-5 (Suswati et al., 2011). Hasil penelitian Maharadingga et al. (2009), isolat Glomus tipe 1 mampu menekan perkembangan penyakit Fusarium oxysporum f.sp. cubense, meningkatkan ketahanan semaian cabai merah terhadap Sclerotium roolfsii, memperpanjang masa inkubasi BDB pada pisang cavendish (Yefriwati et al., 2005). Aplikasi Glomus tipe 1, Acaulospora tipe 4 dan Glomus fasciculatum dapat meningkatkan ketahanan tanaman pisang barangan terhadap BDB. Teraktivasinya mekanisme ketahanan tanaman pisang barangan terhadap BDB dapat dilihat pada penekanan intensitas serangan dan terjadinya perpanjangan masa inkubasi pada tanaman yang terserang BDB (Suswati et al., 2013). Mikoriza dapat menginduksi ketahanan tanaman terhadap patogen-patogen akar (Colditz et al., 2005).

Efek induksi sistemis FMA indigenus dapat melindungi tanaman pisang dari serangan BDB. Pada tanaman yang terinduksi terjadi penekanan berbagai parameter penyakit seperti rendahnya persentase, intensitas serangan, perpanjangan masa inkubasi, proses kematian tanaman, rendahnya populasi BDB dalam jaringan tanaman dan tertekannya perkembangan gejala penyakit. Menurut García-Garrido \& Ocampo (2002), isolat FMA memiliki potensi sebagai induser yang dapat menginduksi ketahanan tanaman terhadap patogen dengan cara mengaktivasi reaksi ketahanan lokal dan sistemik tanaman.

Aplikasi FMA pada tanaman akan menyebabkan perubahan global pada tanaman yang akan mengaktivasi gen-gen ketahanan tanaman dan melindungi tanaman dari serangan patogen (Bent, 1996; Blee \& Anderson, 1996; Harrison \& Dixon, 1993; Ruiz-Lozano et al., 1999a; 1999b). Proses tersebut melibatkan berbagai mekanisme pertahanan tanaman yang berkaitan dengan perubahan respon fisiologis dan biokimia tanaman yang melibatkan induksi enzim-enzim hidrolitik seperti: peroksidase (Pozo et al., 1999; Gianinazzi et al., 1992). Menurut van Loon et al. (1994), enzim peroksidase merupakan suatu kelompok PR-protein (pathogenesis related protein) dari golongan PR-9 yang terakumulasi pada saat tanaman terinfeksi oleh patogen atau terkolonisasi oleh agensia hayati seperti mikoriza. Enzim peroksidase adalah senyawa yang mengkatalis reaksi oksidasi hydrogen peroksida dengan monomer-monomer lignin seperti: r-kumaril alkohol, koniferil alkohol dan sinapsisi alkohol menjadi polimer berupa lignin. Dengan keberadaan lignin maka dinding sel tumbuhan menjadi lebih tebal sehingga sulit untuk dipenetrasi patogen (Hopkins et al., 2001). 
Aktivitas enzim peroksidase dilaporkan berperan dalam mekanisme ketahanan terhadap berbagai patogen pada tanaman yang diaplikasi dengan agensia hayati FMA. Terjadi peningkatan aktivitas enzim peroksidase akar tembakau yang diaplikasi Glomus mosseae (Blilou et al., 2000), tanaman bawang putih yang diaplikasi G. versiforme (Spanu et al., 1988). Tanaman Pinus sylvestris L. yang dikolonisasi oleh Laccaria laccata menunjukkan peningkatan aktivitas enzim peroksidase dan enzim phenylalanin amonia liase (PAL) pada akar (Ronald \& Soderhall, 1985).

Mekanisme induksi ketahanan tanaman akan teraktivasi sejak awal proses simbiose mikoriza yang dimulai dengan penetrasi hingga terbentuknya kolonisasi yang mapan (established) (García-Garrido \& Ocampo, 2002). Perubahan serangkaian respon fisiologis dan biokimia tanaman dan efek perlindungannya terhadap berbagai cekaman ditentukan oleh derajat/persentase kolonisasi FMA yang dipengaruhi oleh kesesuaian inangFMA dan lingkungan serta adanya perbedaan morfologi kolonisasi terutama ada/tidaknya arbuskular dan tipe arbuskular (arbuskular spesifik). Peningkatan ketahanan tanaman setelah diinduksi mikoriza berkaitan dengan fase awal perkembangan struktur mikoriza di dalam sel akar tanaman inang yang diawali sejak penetrasi oleh apresorium hingga bentuknya struktur arbuskular (Balestrini et al., 1997). Peningkatan aktivitas enzim peroksidase berhubungan erat dengan perkembangan struktur kolonisasi mikoriza. Pada awal kolonisasi diduga berkaitan dengan aktivitas apresorium dan 48 jsa dimungkinkan karena pada saat itu telah terjadi pembentukan arbuskular di dalam sel korteks akar. Menurut Hayman (1983) fase pembentukan struktur tersebut dapat terjadi 48 jam setelah penetrasi FMA pada spesies yang kompatibel dengan tanaman inang. Menurut Provorov et al. (2002), selama proses pembentukan arbuskular terjadi peningkatan yang rendah aktivitas enzim peroksidase (PO), kitinase dan pektinase dan sintesis PR-protein (PR1) dan peningkatan tersebut hanya terjadi disekitar arbuskular. Spanu \& Bonfante-Fasolo (1988) menemukan aktivitas peroksidase yang tinggi pada dinding sel akar Allium porrum L. pada awal kolonisasi G. versiforme (16 hsa), aktivitas peroksidase tersebut mengalami penurunan hingga menyamai aktivitas peroksidase kontrol pada tanaman umur 50 hari.

Hasil penelitian Gianinazzi-Pearson \& Gianinazzi (1995) menunjukkan adanya peningkatan konsentrasi protein dalam ekstrak akar bermikoriza. Arines et al. (1993) juga menemukan kandungan protein yang tinggi dalam akar Trifolium pretense L. yang dikolonisasi G. mosseae. Selain itu juga terjadi peningkatan gen-gen ketahanan tanaman yang berhubungan dengan protein pada level transkrip mRNA khususnya dalam sel tanaman yang mengandung arbuskular. Terjadi peningkatan gen-gen ketahanan seperti gen yang mengkode hydroxyproline-rich glycoprotein (HRGP) (Balestrini et al., 1997; Blee \& Anderson, 2000), metabolisme enzim phenylpropanoid (Volpin et al., 1994; Harrison \& Dixon, 1993; 1994), enzim yang terlibat dalam metabolisme ROS (reactive oxygen species) (Blee \& Anderson, 2000) dan enzim hydrolase (Salzer $\&$ Boller, 2000). Ditemukan adanya peningkatan jumlah HRGP mRNA di dalam akar tanaman jagung dan buncis yang mengandung arbuskular (Blee \& Anderson, 2000). Jumlah PAL mRNA Medicago sativa yang diintroduksi G.intraradices meningkat $100 \%$ pada $14-18$ hari setelah aplikasi (hsa), kemudian menurun menjadi $75 \%$ pada 18-19 hsa dan menjadi lebih rendah dibanding kontrol pada 21 hsa. Jumlah CHI mRNA meningkat 6 kali pada 14-17 hsa dan menurun dengan cepat pada umur yang lebih tua. Pada saat yang sama hanya terjadi perubahan yang kecil pada tanaman yang tidak diintroduksi $G$. intraradices sementara IFR mRNA tidak terinduksi (Volpin et al., 1995). Menurut Blilou et al. (2000), introduksi G. mosseae pada tanaman padi akan menstimulasi pembentukan gen-gen yang berhubungan dengan lipid transfer protein (LTP), PAL dan akumulasi asam salisilat di akar. Aktivitas tersebut meningkat pada saat terbentuknya apresorium dan penetrasi ke sel epidermis kemudian aktivitasnya menurun setelah terjadi kolonisasi jaringan korteks.

Penelitian ini merupakan penelitian lanjutan dari pengujian peningkatan ketahanan bibit pisang barangan terhadap BDB dengan aplikasi FMA. Sampai sejauh ini penelitian mengenai aktivitas enzim peroksidase tanaman pisang kepok setelah aplikasi FMA Glomus tipe 1 belum pernah dilaporkan. Tujuan penelitian adalah untuk memperoleh data aktivitas enzim peroksidase tanaman pisang kepok dan kandungan protein setelah diaplikasi dengan Glomus tipe 1.

\section{METODE PENELITIAN}

Tempat dan Waktu. Penelitian dilaksanakan di Laboratorium Agroteknologi, Fakultas Pertanian, Universitas Medan Area dan Laboratorium Bioteknologi, Fakultas Pertanian, Universitas Andalas Padang. Penelitian dilaksanakan pada Maret sampai dengan April 2014.

Rancangan Percobaan dan Analisis Data. Pengujian ini menggunakan Rancangan Acak Lengkap (RAL) dengan 3 ulangan. Perlakuan tersebut adalah waktu 
kolonisasi Glomus tipe 1 dengan satuan jam setelah aplikasi (jsa), 6 taraf perlakuan yaitu: A0 = kontrol; A1 $=4 \mathrm{jsa} ; \mathrm{A} 2=12 \mathrm{jsa} ; \mathrm{A} 3=24 \mathrm{jsa} ; \mathrm{A} 4=36 \mathrm{jsa} ; \mathrm{A} 5=48$ jsa; $\mathrm{A} 6=72$ jsa; $\mathrm{A} 7=96$ jsa.

Penyediaan dan Perlakuan Bibit Pisang. Bibit pisang yang digunakan adalah jenis kepok yang berasal dari bibit kultur jaringan yang telah diaklimatisasi selama 1,5 bulan. Bibit pisang diperoleh dari Balai Penelitian Buah Tropika Aripan Solok. Selanjutnya bibit pisang kepok ditanam pada media campuran tanah dan pupuk kandang dan arang sekam (3:1:1) yang telah disterilisasi dan diadaptasikan selama 14 hari.

Aplikasi Glomus Tipe 1. Sumber inokulan Glomus tipe 1 yang digunakan adalah hasil panen segar dengan tanaman indikator jagung yang ditanam dalam polibag berisi media tanam campuran pasir : arang sekam steril (3:1) dan pemupukan Hyponex cair. Pengamatan persentase kolonisasi, intensitas kolonisasi dan jumlah kepadatan spora akar jagung umur 2 bulan setelah tanam (bst) dilakukan dengan metode slide (Giovannetti \& Mosse, 1980) terhadap 20 potongan yang telah dipreparasi dengan tehnik pewarnaan Kormanick \& McGraw (1982) dan dilakukan penghitungan kepadatan spora menggunakan metode tuang saring (Gerdemann \& Nicolson, 1963), persentase dan kelas intensitas kolonisasi Glomus tipe 1 ditemukan dalam jumlah tinggi dengan persentase kolonisasi $83 \%$, kelas intensitas kolonisasi 4 dan jumlah spora 24 spora segar/50 g.

Aplikasi Glomus tipe 1 dilakukan pada bibit pisang umur 14 hari setelah tanam di polibag pembesaran. Daerah sekitar pangkal batang dikorek sedalam $5 \mathrm{~cm}$ sehingga tampak perakaran bibit pisang, selanjutnya sebanyak $50 \mathrm{~g}$ inokulan Glomus tipe 1 (gabungan potongan akar terkolonisasi, spora dan hifa eksternal) disebar merata di perakaran bibit pisang selanjutnya lubang ditutup kembali dengan media tanam.

Ekstraksi dan Analisis Enzim Peroksidase. Bibit pisang yang diberi perlakuan dibongkar, tanaman dicuci dengan air kran. Bagian akar dan daun dipotong selanjutnya ditimbang dengan menggunakan timbangan digital. Ekstraksi enzim peroksidase dilakukan menurut metode Saunders \& McClure (1975). Akar dan daun tanaman yang masih muda dipotong-potong sampai halus dan ditimbang sebanyak $1 \mathrm{~g}$ (dilakukan secara terpisah) kemudian jaringan dihancurkan dengan mortar setelah

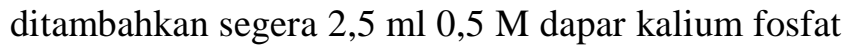
$\mathrm{pH} 7$ dan 0,1 g Polyvinylpolypirolidone (PVP). Campuran tersebut diambil ekstraknya dan disaring dengan dua lapisan kain kasa, disentrifus dengan kecepatan 6000 rpm selama 15 menit pada suhu $4{ }^{\circ} \mathrm{C}$. Supernatan berupa ekstrak enzim digunakan untuk pengukuran kadar protein terlarut dan aktivitas enzim.

Pengukuran aktivitas enzim peroksidase dilakukan dengan cara memasukkan sebanyak $5 \mathrm{ml}$ larutan pirogalol (yang mengandung $0,631 \mathrm{~g}$ pirogalol dan buffer phospat $0,005 \mathrm{~m}$ pH 6 volume akhir $100 \mathrm{ml}$ ) ke dalam tabung reaksi kemudian ditambahkan $0,2 \mathrm{ml}$ ekstrak enzim. Nilai serapan diukur pada panjang gelombang maksimum $420 \mathrm{~nm}$ menggunakan Spektrofotometer UVVis 1700. PharmaSpec. $\left(\right.$ Shimadzu $\left.^{\circledR}\right)$. Larutan buffer dengan ekstrak enzim ditambah dengan $0,5 \mathrm{ml} \mathrm{H}_{2} \mathrm{O}_{2}$ $1 \%$. Larutan diinkubasi selama 5 menit untuk ekstrak kontrol (bagian daun) dan 30 menit untuk ekstrak sampel perlakuan (bagian daun dan akar). Nilai absorbansi diukur kembali dan diamati perubahannya.

Pengukuran Kadar Protein Terlarut. Pembuatan kurva standar larutan protein Bovine Serum Albumin (BSA) dilakukan berdasarkan metode Lowry (1951) dalam Edelstein \& Bollag (1991). Pada sederetan tabung reaksi dimasukkan larutan standar protein BSA dengan variasi konsentrasi $0 ; 0,1 ; 0,2 ; 0,3 ; 0,4 ;$ dan $0,5 \mathrm{mg} / \mathrm{ml}$. Selanjutnya ditambahkan $5 \mathrm{ml}$ reagen Lowry C dan diaduk, kemudian ditambahkan $1 \mathrm{ml}$ reagen Lowry D dan segera diaduk dengan magnetic stirer. Larutan disimpan pada suhu ruang $\left(29^{\circ} \mathrm{C}\right)$ selama 30 menit dan dilanjutkan dengan pengukuran serapan pada panjang gelombang maksimum $750 \mathrm{~nm}$ menggunakan Spektrofotometer UV-Vis 1700. PharmaSpec. $\left(\right.$ Shimadzu $\left.^{\circledR}\right)$. Sebagai blanko larutan standar diganti dengan akuades.

Penentuan kadar protein terlarut dilakukan berdasarkan metode Lowry (1951) dalam Edelstein \& Bollag (1991). Kadar protein terlarut sampel ditentukan dengan metode kalibrasi larutan standar BSA. Sebanyak $1 \mathrm{ml}$ ekstrak sampel ditambahkan dengan $5 \mathrm{ml}$ reagen Lowry $\mathrm{C}$, kemudian diaduk dan selanjutnya ditambahkan $1 \mathrm{ml}$ Lowry D. Larutan tersebut disimpan pada suhu ruang $\left(29^{\circ} \mathrm{C}\right)$ selama 30 menit, selanjutnya dilakukan pengukuran serapan pada panjang gelombang maksimum $750 \mathrm{~nm}$.

Pengamatan. Aktivitas enzim peroksidase di dalam jaringan daun ditentukan dengan rumus:

Aktivitas enzim peroksidase (unit) $=\frac{\text { konsentrasi enzim }}{\text { waktu inkubasi (menit) }}$ 


\section{HASIL DAN PEMBAHASAN}

Aktivitas Enzim Peroksidase. Kolonisasi Glomus tipe 1 pada tanaman pisang kepok menyebabkan perubahan aktivitas enzim peroksidase yang direspon secara berbeda oleh jaringan akar dan daun. Pada awal kolonisasi (4 jsa) terjadi peningkatan yang rendah aktivitas enzim peroksidase akar sebesar 5,84\% (0,326 U). Aktivitas enzim tersebut menurun seiring dengan pertambahan waktu kolonisasi Glomus tipe 1. Penurunan aktivitas enzim peroksidase tertinggi $(10,39 \%)$ ditemukan pada 36 jsa $(0,279 \mathrm{U})$, sementara aktivitas enzim peroksidase ditemukan dalam jumlah yang sama $(0,308 \mathrm{U})$ pada 24 jsa dan 72 jsa. Tingkat aktivitas enzim tersebut sama dengan aktivitas tanaman tanpa aplikasi Glomus tipe 1 (kontrol) (Tabel 1).

Sebaliknya aplikasi Glomus tipe 1 menyebabkan penurunan yang tinggi terhadap aktivitas enzim peroksidase daun sebesar 85,83-87,37\%. Aktivitas enzim peroksidase sebelum aplikasi Glomus tipe 1 sebesar 2,301 U kemudian menurun menjadi 0,326 U pada awal kolonisasi (4 jsa). Penurunan aktivitas enzim tersebut masih tetap berlangsung hingga 96 jsa $(0,308 \mathrm{U})$. Kondisi tersebut mengakibatkan penurunan aktivitas total enzim peroksidase. Pada awal kolonisasi Glomus tipe 1 (4 jsa) terjadi penurunan aktivitas total enzim sebesar $79,99 \%$, persentase penekanan semakin meningkat seiring dengan peningkatan waktu kolonisasi mikoriza. Penekanan aktivitas total enzim peroksidase tertinggi ditemukan pada 36 jsa $(97,58 \%)$.

Aplikasi FMA menyebabkan perubahan global pada tanaman yang akan mengaktivasi gen-gen ketahanan tanaman dan melindungi tanaman dari serangan patogen. Perubahan global tersebut direspon secara berbeda oleh jaringan akar dan daun. Kolonisasi
Glomus tipe 1 dalam perakaran tanaman pisang kepok menyebabkan perubahan aktivitas enzim peroksidase dan kandungan protein dalam bagian akar dan daun. Pada awal kolonisasi Glomus tipe 1 (4-24 jsa) terjadi peningkatan aktivitas enzim peroksidase kemudian menurun pada 36 jsa, meningkat kembali pada 48-72 jsa dan menurun kembali pada 96 jsa. Dapat dikatakan bahwa aktivitas enzim peroksidase mengalami fluktuasi di dalam perakaran tanaman pisang kepok, sementara aktivitas enzim peroksidase cenderung menurun di dalam daun. Adanya perbedaan ini disebabkan oleh jaringan akar merupakan tempat masuk (point of entrance) dan kolonisasi mikoriza sehingga fokus respon fisiologis tanaman pisang diprioritaskan pada akar.

Teraktivasinya ketahanan tanaman pisang kepok setelah aplikasi Glomus tipe 1 melalui perubahan aktifitas enzim peroksidase berkaitan erat dengan penurunan intensitas serangan BDB pada tanaman yang terserang. Pada pengujian pendahuluan tentang peningkatan ketahanan pisang barangan terhadap BDB setelah aplikasi FMA diperoleh hasil bahwa FMA dapat menekan persentase penyakit, intensitas serangan BDB dan memperpanjang masa inkubasi bakteri pada tanaman pisang barangan yang terserang BDB (Suswati et al., 2011; Yefriwati et al., 2005). Peningkatan ketahanan tanaman pisang barangan, pisang kepok terhadap BDB berkaitan erat dengan perkembangan kolonisasi Glomus tipe 1 dalam perakaran tanaman pisang. Pada awal kolonisasi diduga berkaitan dengan aktivitas apresorium dan 48 jsa dimungkinkan karena pada saat itu telah terjadi pembentukan arbuskular di dalam sel korteks akar. Menurut Hayman (1983), fase pembentukan struktur tersebut dapat terjadi 48 jam setelah penetrasi FMA pada spesies yang kompatibel dengan tanaman inang. Menurut Provorov et al. (2002),

Tabel 1. Aktivitas enzim peroksidase (U) dan perubahan aktivitas (\%) pada akar dan daun tanaman pisang kepok setelah aplikasi Glomus tipe 1

\begin{tabular}{lccccccc}
\hline \multirow{2}{*}{ Perlakuan } & \multicolumn{3}{c}{ Aktivitas enzim peroksidase (U) dan peningkatan aktivitas (\%) dibanding kontrol } \\
\cline { 2 - 7 } & $\begin{array}{c}\text { Waktu } \\
\text { (jam) }\end{array}$ & \multicolumn{2}{c}{ Akar } & \multicolumn{2}{c}{ Daun } & \multicolumn{2}{c}{ Total } \\
\cline { 2 - 7 } & Aktivitas & Perubahan & Aktivitas & Perubahan & Aktivitas & Perubahan \\
\hline \multirow{2}{*}{ Kontrol } & 0 & 0,308 & 0,00 & 2,301 & 0,00 & 2,609 & 0,00 \\
Glomus tipe 1 & 4 & 0,326 & 5,84 & 0,326 & $-85,83$ & 0,652 & $-79,99$ \\
& 12 & 0,320 & 3,90 & 0,290 & $-87,37$ & 0,610 & $-83,47$ \\
& 24 & 0,308 & 0,00 & 0,308 & $-86,8$ & 0,616 & $-86,58$ \\
& 36 & 0,276 & $-10,39$ & 0,294 & $-87,19$ & 0,570 & $-97,58$ \\
& 48 & 0,314 & 1,95 & 0,308 & $-86,58$ & 0,622 & $-84,63$ \\
& 72 & 0,308 & 0,00 & 0,308 & $-86,58$ & 0,616 & $-86,58$ \\
& 96 & 0,279 & $-9,42$ & 0,308 & $-86,58$ & 0,587 & $-95,99$ \\
\hline
\end{tabular}


selama proses pembentukan arbuskular terjadi peningkatan yang rendah aktivitas enzim peroksidase (PO), kitinase dan pektinase dan sintesis PR-protein (PR1) dan peningkatan tersebut hanya terjadi di sekitar arbuskular. Cepatnya perkembangan arbuskular di dalam sel kortek tanaman pisang kepok berkaitan dengan tingginya tingkat kompatibilitas tanaman pisang kepok terhadap mikoriza. Glomus tipe 1 yang digunakan dalam penelitian ini merupakan mikoriza indigenus yang berasal dari rizosfer tanaman pisang kepok.

Selain derajat kolonisasi (persentase dan intensitas kolonisasi FMA), perubahan aktivitas enzim peroksidase dan kandungan protein juga dipengaruhi oleh kesesuaian inang-FMA dan lingkungan. Konsep gen-for-gen ditemukan dalam interaksi FMA dengan tanaman inang. Tanaman Medicago truncatula yang diintroduksi 3 spesies FMA: G. intraradices, G. mosseae dan Scutellospora castanea memiliki struktur kolonisasi yang berbeda. Setelah 10 minggu kolonisasi ditemukan derajat kolonisasi ketiga spesies FMA tersebut berbeda. Tingkat kolonisasi G. intraradices 58,2\%, G. mosseae $23,2 \%$ dan $S$. castanea $10,4 \%$. Perbedaan morfologi kolonisasi terutama ada/tidaknya arbuskular dan tipe arbuskular (arbuskular spesifik) akan mempengarui ekspresi gen-gen yang berbeda melalui jalur transduksi sinyal yang berbeda. Dalam jaringan korteks yang mengandung struktur arbuskular ditemukan ekspresi gen-gen yang berkaitan dengan pertahanan tanaman secara signifikan (Burleigh \& Harrison, 1999). Menurut Habazar \& Rivai (2000), terjadinya perubahan aktivitas enzim peroksidase yang disintesis oleh sel tanaman selama proses kolonisasi mikoriza bervariasi tergantung pada berbagai varietas tanaman, tipe jaringan dan tipe patogen. Produksi senyawa tersebut dalam skala besar hanya terdapat pada kombinasi spesies mikoriza dan varietas inang yang inkompatibel tetapi juga ditemukan dalam kadar rendah dalam kombinasi kompatibel.

Kadar protein. Kolonisasi Glomus tipe 1 pada tanaman pisang kepok menyebabkan perubahan kadar protein akar dan daun (Tabel 2). Secara umum aplikasi Glomus tipe 1 dapat meningkatkan kandungan protein akar sejak awal kolonisasi (4 jsa) sebesar 19,88 \% (4,975 mg/ml) hingga 96 jsa dengan kandungan protein tertinggi yaitu $70,60 \%(7,080 \mathrm{mg} / \mathrm{ml})$. Sebaliknya pada saat yang bersamaan terjadi penurunan kandungan protein di dalam daun. Penurunan kandungan protein tersebut terjadi sejak awal kolonisasi sebesar 7,65\%, kandungan protein semakin berkurang seiring dengan bertambahnya waktu kolonisasi Glomus tipe 1. Kandungan protein terendah daun ditemukan pada saat 96 jsa yaitu 2,390 $\mathrm{mg} / \mathrm{ml}$. Walaupun terjadi penurunan kandungan protein di dalam daun, tetapi kandungan protein total tanaman pisang kepok masih ditemukan dalam jumlah sedikit lebih tinggi pada 4 jsa yaitu $12,23 \%(12,580 \mathrm{mg} / \mathrm{ml})$ dibanding kontrol (12,385 mg/ml) (Tabel 2).

Aplikasi FMA mampu meningkatkan kandungan protein akar sejak awal kolonisasi (4 jsa) sebesar 19,88\% (4,975 mg/ml) hingga 96 jsa dengan kandungan protein tertinggi yaitu $70,60 \%(7,080 \mathrm{mg} / \mathrm{ml})$. Sebaliknya pada saat yang bersamaan terjadi penurunan kandungan protein di dalam daun. Hasil penelitian yang diperoleh sesuai dengan berbagai penelitian mengenai peningkatan kandungan protein pada berbagai tanaman yang diintroduksi mikoriza. Menurut beberapa peneliti (Spanu et al., 1989; Lambais \& Mehdy, 1993; Vierheilig et al., 1994; Volpin et al., 1994) introduksi mikoriza menyebabkan terjadinya peningkatan PR protein

Tabel 2. Kadar protein dan perubahannya pada akar dan daun tanaman pisang kepok setelah aplikasi Glomus tipe 1

\begin{tabular}{lccccccc}
\hline & \multirow{2}{*}{$\begin{array}{c}\text { Waktu } \\
\text { Polonisasi } \\
\text { Pam) }\end{array}$} & $\begin{array}{c}\text { Kadar } \\
\text { protein } \\
(\mathrm{mg})\end{array}$ & $\begin{array}{c}\text { Perubahan } \\
(\%)\end{array}$ & $\begin{array}{c}\text { Kadar } \\
\text { protein } \\
(\mathrm{mg})\end{array}$ & $\begin{array}{c}\text { Perubahan } \\
(\%)\end{array}$ & $\begin{array}{c}\text { Kadar } \\
\text { protein } \\
(\mathrm{mg})\end{array}$ & $\begin{array}{c}\text { Perubahan } \\
(\%)\end{array}$ \\
\hline Kontrol (tanpa & & & & & & & \\
Glomus tipe 1) & 4 & 4,150 & 0,00 & 8,235 & 0,00 & 12,385 & 0,00 \\
Glomus tipe 1 & 4,975 & 19,88 & 7,605 & $-7,65$ & 12,580 & 12,23 \\
& 12 & 4,635 & 11,69 & 5,750 & $-30,18$ & 10,385 & $-18,49$ \\
& 24 & 5,425 & 30,72 & 5,760 & $-30,05$ & 11,185 & $-0,67$ \\
& 36 & 4,980 & 20,00 & 5,220 & $-36,61$ & 10,200 & $-16,61$ \\
& 48 & 5,595 & 34,82 & 5,055 & $-38,62$ & 10,650 & $-3,79$ \\
& 72 & 5,885 & 41,81 & 5,030 & $-38,92$ & 10,915 & $-2,89$ \\
& 96 & 7,080 & 70,60 & 2,390 & $-70,98$ & 9,470 & $-0,38$ \\
\hline
\end{tabular}


(kitinase dan B-1,3-glukanase), dimana kadar protein tersebut meningkat pada awal interaksi tanaman-FMA dan kadar/aktivitasnya sangat berkurang seiring dengan peningkatan kolonisasi mikoriza. Menurut GianinazziPearson \& Gianinazzi (1995) tanaman inang menghasilkan sejumlah protein baru (endomycorrhizins) sebagai respon terhadap kolonisasi FMA selain itu terjadi penambahan polipeptida baru (García-Garrido et al., 1993; Dumas-Gaudot et al., 1994) dan beberapa polipeptida menghilang (DumasGaudot et al., 1994). Pada berbagai kasus ditemukan penurunan kadar protein pada tanaman yang bermikoriza. Terjadi penurunan kadar protein tanaman tembakau yang mengekspresikan gen PR-1 dan akumulasi protein yang berhubungan dengan ketahanan tanaman (Ginzberg et al., 1998).

Aplikasi FMA menyebabkan perubahan global pada tanaman yang akan mengaktivasi gen-gen ketahanan tanaman dan melindungi tanaman dari serangan patogen. Perubahan global tersebut direspon secara berbeda oleh jaringan akar dan daun. Hasil analisis molekuler terhadap ekspresi gen-gen ketahanan tanaman pisang Kepok (Saba, Group ABB) yang diintroduksi Glomus clarum ditemukan peningkatan mRNA daun $22,137 \%$ sementara terjadi penekanan 2,99\% di akar. Terjadi peningkatan ekspresi gen-gen ketahanan seperti: Catalase 2 mRNA 2,40 kali, PR1 mRNA 1,70 kali dan Endochitinase mRNA 0,60 kali sementara di daun hanya ditemukan peningkatan Endochitinase mRNA 0,10 kali (Suswati, 2010). Menurut Volpin et al. (1995), terjadi peningkatan gen-gen ketahanan pada tanaman Medicago sativa yang diintroduksi Glomus intraradices. Jumlah PAL mRNA M. sativa meningkat $100 \%$ pada $14-18$ hsa kemudian menurun menjadi $75 \%$ pada $18-19$ hsa dan menjadi lebih rendah dibanding kontrol pada 21 hsa. Jumlah CHI mRNA meningkat 6 kali pada 14-17 hsa dan menurun dengan cepat pada umur yang lebih tua. Pada saat yang sama hanya terjadi perubahan yang kecil pada tanaman yang tidak diintroduksi $G$. intraradices sementara IFR mRNA tidak terinduksi.

Gen mRNA terlibat dalam katabolisme ROS (reactive oxygen species) seperti katalase dan peroksidase yang ditemukan dalam sel korteks buncis dan gandum yang mengandung arbuskular (Blee \& Anderson, 2000). Katalase dan peroksidase memainkan peranan penting dalam katabolisme hidrogen peroksida dan/atau reaksi ikatan silang (cross linking) antara protein dan polisakarida pada daerah interface antara arbuskular dan membran plasma sel tanaman. Besarnya perubahan gen-gen yang terlibat dipengaruhi oleh berbagai faktor diantaranya genotip inang (Berta et al., 1990; Schellenbaum et al., 1991; Tisserant et al., 1992), kondisi tapak (site), spesies FMA, derajat kolonisasi, fase pertumbuhan tanaman, tipe jaringan, waktu aplikasi FMA, isolat patogen (Singh et al., 2000; Whipps, 2004, Lackie et al., 1987; Hetrick et al., 1993; Vierheilig \& Ocampo, 1990; 1991).

\section{SIMPULAN}

Secara umum ditemukan bahwa aplikasi Glomus tipe 1 dapat menginduksi ketahanan tanaman pisang kepok terhadap BDB melalui aktivasi enzim peroksidase dan kandungan protein dalam akar dan daun tanaman pisang. Pada tanaman pisang yang terinduksi ketahanannya ditemukan persentase serangan, intensitas serangan BDB yang lebih rendah dan munculnya gejala awal penyakit menjadi lebih lama dibanding pada kontrol (tanpa FMA).

\section{SANWACANA}

Pada kesempatan ini penulis mengucapkan terima kasih kepada Ditjen Dikti yang telah memberikan dana penelitian Direktorat Penelitian dan Pengabdian kepada Masyarakat Direktorat Jenderal Pendidikan Tinggi Kementerian Pendidikan dan Kebudayaaan sesuai dengan Surat Perjanjian Pelaksanaan Penugasan Penelitian Strategis Nasional Nomor: DIPA Kopertis Wilayah I Tahun 2014 dan sesuai dengan Surat Perjanjian/Penugasan dalam Rangka Pelaksanaan Program Penelitian Strategis Nasional Nomor 02304.2.415052/2013 tanggal 5 Desember 2013.

\section{DAFTAR PUSTAKA}

Arines J, Palma JM, \& Vilarino A. 1993. Comparison of protein patterns in non-mycorrhizal and vesicular-arbuscular mycorrhizal roots of red clover. Phytopathol. 123: 763-765.

Azcon-Aguilar C, Jaizme-Vega MC, \& Calvet C. 2002. The contribution of arbuscular mycorrhizal fungi to the control of soil-borne plant pathogens. In: Gianinazzi S, Schuepp H, Barea JM, \& Haselwandter K (Eds.). Mycorrhizal Technology in Agriculture. pp. 187-197. Birkhauser, Switzerland. 
Balestrini R, Josè-Estanyol M, Puigdomènech P, \& Bonfante P. 1997. Hydroxyproline-rich glycoprotein mRNA accumulation in maize root cells colonized by an arbuscular mycorrhizal fungus as revealed by in situ hybridization. Protoplasma 198(1): 36-42.

Bent AF. 1996. Plant disease resistance genes: function meets structure. Plant Cell 8(10): 1757-1771.

Berta G, Fusconi A, Trotta A, \& Scannerini S. 1990. Morphogenetic modification induced by the mycorrhizal fungus Glomus strain $\mathrm{E}_{3}$ in the root system of Allium porrum L. Phytopathol. 114: 207-215.

Blee KA \& Anderson AJ. 1996. Defense-related transcript accumulation in Phaseolus vulgaris L. colonized by the arbuscular mycorrhizal fungus Glomus intraradices Schenck \& Smith. Plant Physiol. 110(2): 675-688.

Blee KA \& Anderson AJ. 2000. Defense responses to arbuscular mycorrhizal fungi. In: Podila GK \& Douds DD (Eds.). Current Advances in Mycorrhizae Research. pp. 27-44. The American Phytopathological Society, St. Paul.

Blilou I, Ocampo JA, \& García-Garrido JM. 2000. Induction of Ltp (lipid traner protein) and Pal (phenylalanine ammonia-lyase) gene expression in rice roots colonized by the arbuscular mycorrhizal fungus Glomus mosseae. J. Exp. Bot. 51(353): 1969-1977.

Buddenhagen IW \& Elsasser TA. 1962. An Insectspread bacterial wild epiphytotic of bluggoe banana. Nature 194: 146-165.

Burleigh SH \& Harrison MJ. 1999. The down-regulation of Mt4-like genes by phosphate fertilization occurs systemically and involves phosphate translocation to the shoots. Plant Physiol. 119: 241-248.

Colditz F, Braun HP, Jacquet C, Niehaus K, \& Krajinski F. 2005. Proteomic profiling unravels insight into the molecular background underlying increased Aphanomyces euteiches tolerance of Medicago truncatula. Plant Mol. Biol. 59(3): 387-406.

Dumas-Gaudot E, Asselin A, Gianinazzi-Pearson V, Gollette A, \& Gianinazzi S. 1994. Chitinase isoforms in roots of various pea genotypes infected with arbuscular mycorrhizal fungi. Plant Sci. 99(1): 27-37.
Eden-Green SJ. 1992. Characteristics of Pseudomonas solanacearum and related bacteria frombanana and plantain in South East Asia. In: Lemattre M, Freigoun S, Rudolph K, \& Swings JG (Eds.). Plant Pathogenic Bacteria. pp. 51-57. INRA editions, Paris.

Edelstein SJ \& Bollag DM. 1991. Protein methods. A John Wiley \& Sons, Inc Publication, New York.

Garcia-Garrido JM \& Ocampo JA. 2002. Regulation of the plant defence response in arbuscular mycorrhizal symbiosis. J. Exp. Bot. 53: 13771386.

García-Garrido JM, Toro N, \& Ocampo JA. 1993. Presence of specific polypeptides in onion roots colonized by Glomus mosseae. Mycorrhiza 2(4): 175-177.

Gerdemann JW \& Nicolson TH. 1963. Spores of mychorrhizal endogone species extracted from soil by wet sleving and decanting. Trans. Brit. Mycol. Soc. 46(2): 234-244.

Gianinazzi-Pearson V \& Gianinazzi S. 1995. Immunodetection of infection thread glycoprotein and arabinogalactan protein in wild type Pisum sativum (L.) or an isogenic mycorrhiza-resistant mutant interacting with Glomus mosseae. Symbiosis 18: 69-85.

Gianinazzi S, Gianinazzi-Pearson V, Tisserant B, \& Lemoine MC. 1992. Protein activities as potential markers of functional endomycrrhizas in planta. In: Read DJ, Lewis DH, Fitter AH, \& Alexander IJ (Eds.). Mycorrhizas in ecosystems. pp. 333339. CAB International, Wallingford.

Ginzberg I, David-Schwartz R, Shaul O, Elad Y, Wininger S, Ben-Dor B, Badani H, Fang Y, van Rhijn P, Li Y, Hirsch AM, \& Kapulnik Y. 1998. Glomus intraradices colonization regulates gene expression in tobacco plants. Symbiosis 25(1-3): 145-157.

Giovannetti M \& Mosse B. 1980. An evaluation of techniques for measuring vesicular-arbuscular mycorrhizal infection in roots. New Phytol. 84(3): 489-500.

Habazar T \& Rivai F. 2000. Dasar-Dasar Bakteri Patogenik Tumbuhan. Fakultas Pertanian Universitas Andalas, Padang. 
Harrison MJ \& Dixon RA. 1993. Isoflavonoid accumulation and expression of defense gene transcripts during the establishment of vesiculararbuscular mycorrhizal associations in roots of Medicago truncatula. Mol. Plant Microbe Interact. 6(5): 643-654.

Harrison MJ \& Dixon RA. 1994. Spatial patterns of expression of flavonoid/isoflavonoid pathways genes during interactions between roots of Medicago truncatula and the mycorrhizal fungus Glomus vesiforme. Plant J. 6(1): 9-20.

Hayman DS. 1983. The physiology of vesiculararbuscular endomycorrhizal symbiosis. Can. J. Bot. 61: 944-963.

Hetrick BAD, Wilson GWT, \& Cox TS. 1993. Mycorrhizal dependence of modern wheat cultivars and ancestors: a synthesis. Can. J. Bot. 71(3): 512-518.

Hopkins DW, Webster EA, Chudek JA, \& Halpin C. 2001. Decomposition in soil of tobacco plants with genetic modifications to lignin biosynthesis. Soil Biol. Biochem. 33: 1455-1462.

Kormanick PP \& McGraw AC. 1982. Quantification of vesicular-arbuscular mycorrhiza in plant roots. In: Schenck NC (Ed.). Methods and Principles of Mycorrhizal Research. pp. 37-45. The American Phytopathological Society. St. Paul, Minnesota, USA.

Lackie SM, Garriock ML, Peterson RL, \& Bowley SR. 1987. Influence of host plant on the morphology of the vesicular-arbuscular mycorrhizal fungus Glomus versiforme (Daniels and Trappe) Berch. Symbiosis 3: 147-158.

Lambais MR \& Mehdy MC. 1993. Suppression of endochitinase, $\beta$-1,3-endoglucanase, and chalcone isomerase expression in bean vesicular-arbuscular mycorrhizal roots under different soil phosphate conditions. Mol. Plant Microbe Interact. 6(1): 75-83.

Maharadingga. 2009. Efektivitas beberapa isolat fungi mikoriza arbuskula (FMA) dalam menekan perkembangan penyakit layu fusarium pada bibit pisang kultivar kepok. Skripsi. Universitas Andalas. Padang.
Ploetz RC. 1990. Population biology of Fusarium oxysporum f.sp. cubense. In: Ploetz RC (Ed.). Fusarium Wilt of Banana. pp. 63-76. The American Phytopathological Society, St Paul.

Pozo MJ, Azcón-Aguilar C, Dumas-Gaudot E, \& Barea JM. 1999. ß-1,3-glucanase activities in tomato roots inoculated with arbuscular mycorrhizal fungi and/or Phytophthora parasitica and their possible involvement in bioprotection. Plant Sci. 141: 149-157.

Provorov NA, Borisov AY, \& Tikhonovich IA. 2002. Developmental genetics and evolution of symbiotic structures in nitrogen-fixing nodules and arbuscular mycorrhiza. J. Theor. Biol. 214(2): 215-232.

Ronald P \& Soderhall K. 1985. Phenylalanine ammonia lyase and peroxidase activity in mycorrhizal and nonmycorrhizal short roots of Scots pine, Pinus sylvestris L. Phytopathol.101(1): 487-494.

Ruiz-Lozano JM, Gianinazzi S, \& Gianinazzi-Pearson V. 1999a. Genes involved in resistance to powdery mildew in barley differentially modulated root colonization by the mycorrhizal fungus Glomus mosseae. Mycorrhiza 9: 237-240.

Ruiz-Lozano JM, Roussel H, Gianinazzi S, \& GianinazziPearson V. 1999b. Defense genes are differentially induced by a mycorrhizal fungus and Rhizobium sp. in wild-type and symbiosisdefective pea genotypes. Mol. Plant Microbe Interact. 12(11): 976-984.

Salzer P \& Boller T. 2000. Elicitor induced reactions in mycorrhizae and their suppression. In: Podila GK \& Douds DD (Eds.). Current Advances in Mycorrhizae Research. pp. 1-10. The American Phytopathological Society, St. Paul.

Saunders JA \& McClure JW. 1975. The distribution of flavonoids in chloroplasts of twenty five species of vascular plants. Phytochemistry 15: 809-810.

Schellenbaum L, Berta G, Ravolanirina F, Tisserant B, Gianinazzi S, \& Fitter AH. 1991. Influence of endomycorrhizal infection on root morphology in a micropropagated woody plant species (Vitis vinifera L.). Ann. Bot. 68(2): 135-141. 
Singh R, Adholeya A, \& Mukerji KG. 2000. Mycorrhiza in control of soil-borne pathogens. In: Mukerji KG, Chamola BP, \& Singh J (Eds.). Mycorrhizal Biology. pp. 173-196. Kluwer, New York.

Spanu P \& Bonfante-Fasolo P. 1988. Cell wall bound peroxidase activity in roots of Mycorrhizal Allium porrum. Phytopathol. 109: 119-124.

Spanu P, Boller T, Ludwig A, Wiemken A, Faccio A, \& Bonfante-Fasolo P. 1989. Chitinase in roots of mycorrhizal Allium porrum: regulation and localization. Planta 177(4): 447-455.

St-Arnaud M \& Elsen A. 2005. Interaction of arbuscular mycorrhizal fungi with soil-borne pathogens and non-pathogenic rhizosphere micro-organisms. In: Declerck S, Strullu DG, \& Fortin A (Eds.). In Vitro Culture of Mycorrhizas. pp. 217-231. Springer, Heidelberg. Berlin.

St-Arnaud M \& Vujanovic V. 2007. Effect of the arbuscular mycorrhizal symbiosis on plant diseases and pests. In: Hamel C \& Plenchette $C$ (Eds.). pp. 67-122. Mycorrhizae in Crop Production. Haworth, Binghampton,.

Sulyo Y. 1992. Major banana disease and their control. IARD Journal 14 (3 and 4): 55-62.

Suswati, Habazar T, Rivai F, \& Putra DP. 2007. Peningkatan Ketahanan Tanaman Bawang Merah (Allium ascalonicum L.) dengan Cendawan Mikoriza Arbuskular terhadap Penyakit Hawar Daun (Xanthomonas axonopodis pv. allii). Konggres Asosiasi Mikoriza Indonesia II. pp. 34-37. Institut Pertanian Bogor. Bogor. 17-21 Juli 2007.

Suswati. 2010. Aplikasi pisang kepok dengan Mikoriza. Laporan Program Sandwich. Program Pascasarjana, Universitas Andalas. (Tidak dipublikasi).

Suswati, Habazar T, Nasir N, \& Putra DP. 2011. Respon Fisiologis Tanaman Pisang dengan Introduksi Fungi Mikoriza Arbuskular Indigenus terhadap Penyakit Darah Bakteri (Ralstonia solanacearum Phylotipe IV). https:// w w w. google.co.id/? g w s r d = c r, s s $1 \&$ e i $=0$ B y P V v G W F t Wi u g S f $7 \mathrm{bmgBQ} \# \mathrm{q}=+$ suswat $i+$ blood +disease+ bacterium\%2Cpisang. Diakses pada 8 Januari 2016.
Suswati, Nasril N, \& Azwana. 2013. Peningkatan ketahanan tanaman pisang barangan terhadap Blood disease bacterium (BDB) dengan aplikasi fungi mikoriza arbuskular indigenus. J. HPT Tropika 13(1): 96-104.

Tisserant B, Schellenbaum L, Gianinazzi-Pearson V,Gianinazzi S, \& Berta G. 1992. Influence of infection by an endomycorrhizal fungus on root development and architecture in Platanus acerifolia. Allionia 30: 171-181.

Van Loon LC, Pierpoint WS, Boller T, \& Conejero V. 1994. Recommendations for naming plant pathogenesis-related proteins. Plant Molecular Biology Reporter 12: 245-264.

Vierheilig H \& Ocampo JA. 1990. Effect of isothiocyanates on germination of spores of $G$. mosseae. Soil Biol. Biochem. 22(8): 1161-1162.

Vierheilig H \& Ocampo JA. 1991. Receptivity of various wheat cultivars to infection by VA-mycorrhizal fungi as influenced by inoculum potential and the relation of VAM effectiveness to succinic dehydrogenase activity of the mycelium in the roots. Plant Soil 133(2): 291-296.

Vierheilig H, Alt M, Mohr U, Boller T, \& Wiemken A. 1994. Ethylene biosynthesis and activities of chitinase and s-1,3-glucanase in the roots of host and non-host plants of vesicular-arbuscular mycorrhizal fungi after inoculation with Glomus mosseae. J. Plant Physiol. 143: 337-343.

Volpin H, Elkind Y, Okon Y, \& Kapulnik Y. 1994. A vesicular arbuscular mycorrhizal fungus (Glomus intraradix) induces a defense response in alfalfa root. Plant Physiol. 104(2): 683-689.

Volpin H, Philips DA, Okon Y, \& Kapulnik Y. 1995. Suppresion of an isoflavonoid phytoalexin defense response in mycorrhizal alfalfa roots. Plant Physiol. 108(4): 1449-1454.

Wardlaw CW. 1972. Banana Diseases: Including Plantains and Abaca. 2nd edition. Prentice Hall Press, London.

Whipps JM. 2004. Prospects and limitations for mycorrhizas in biocontrol of root pathogens. Can. J. Bot. 82(8): 1198-1227. 
Xavier LJC \& Boyetchko SM. 2004. Arbuscular mycorrhizal fungi in plant disease control. In: Arora DK (Ed.). Fungal Biotechnology in Agricultural, Food, and Environmental Applications. pp. 183-194. Marcel-Dekker Inc. Dekker, New York.
Yefriwati, Habazar T, Reflin, \& Muas I. 2005. Aplikasi beberapa cendawan mikoriza arbuskular dalam meningkatkan ketahanan bibit pisang terhadap serangan penyakit layu bakteri (Ralstonia solanacearum ras 2). Prosiding Seminar Nasional dan Workshop Asosiasi Mikoriza Indonesia. pp. 34-45. Jambi. 9-10 Mei 2005. 